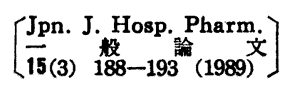

\title{
健常成人におけるバルプロ酸反復投与時の体内動態
}

\author{
児玉庸夫*1, 木本裕郎*1, 安長文隆 ${ }^{* 1}$, 倉成正恵 ${ }^{* 1}$, 都甲雄平*1,

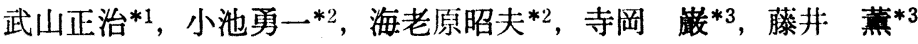 \\ 大分医科大学医学部附属病院薬剂部*1 \\ 大分医科大学医学部臨床薬理学*2 \\ 大分医科大学医学部精神神経医学*3
}

\section{Repeated Dose Kinetics of Valproic Acid in Healthy Adults}

\author{
YASUO KODAMA*1, HIROO KIMOTO*1, FUMITAKA YASUNAGA*1, \\ MASAE KURANARI*1, YUHEI TOGO*1, MASAHARU TAKEYAMA*!, \\ YUICHI KOIKE*2, AKIO EBIHARA*2, IWAO TERAOKA*3, ISAO FUJI*3 \\ Department of Pharmacy, Oita Medical College Hospital*1 \\ Department of Clinical Pharmacology, Medical College of Oita*2 \\ Department ot Neuropsychiatry, Medical College of Oita*3
}

(Received December 20, 1988)

\begin{abstract}
$200 \mathrm{mg}$ of valproic acid (VPA) was orally administered to 7 healthy adults at $9 \mathrm{a} . \mathrm{m}$. and 9 p. $m$. for 5 days. On the 6th day, blood samples were collected at $0,10,20,30,45,60,90$, 180 and $360 \mathrm{~min}$ and the obtained 63 sera were prepared for analysis. There was a significant relationship between VPA dose and total VPA concentration in the serum, the regression curve was $y=0.330 x^{2}+22.051(r=0.469, p<0.001)$. After the last dose, maximum change of total VPA concentration reached at $60 \mathrm{~min}$ and the value was $84.0 \pm 29.9 \%$ (mean \pm S.D. $n=7$ ). Maximum change of unbound VPA fraction reached at $90 \mathrm{~min}$ and the value was $26.6 \pm 33.2 \%$ (mean \pm S.D. $n=7$ ). At $360 \mathrm{~min}$, the coefficient of variation of total VPA concentration change was $30.7 \%$ and that of unbound VPA fraction change was $191.5 \%$. Protein binding of VPA showed a tendency to depend on its total concentration in the serum.
\end{abstract}

Keywords- - sodium valproate; normal adult; multiple dose; dose-concentration relationship; diurnal fluctuation; unbound fraction

\section{緒}

バルプロ酸 (VPA) は重要な抗てんかん薬の一つであ

り，治療域とされている血獎中濃度は，一般飞 50〜100 $\mu \mathrm{g} / \mathrm{ml}$ といわれている゙。 しかし, Schobben らはVPA の治療血墏中濃度域の評価について, 薬理学的・薬物動 態学的な見地からいくつかの問題点を指摘している2). このことは VPA の治療血漿中濃度域の臨床評価がまだ

*1 3 大分県大分郡挾間町医大ヶ 丘 1-1506; 1-1506, Idaigaoka, Hazama-cho, Oita-gun, Oita, 879-56 Japan
完全でないことを示しており，その理由の一つとして VPA の投与量と血墏中湛度との間にみられる大きな個

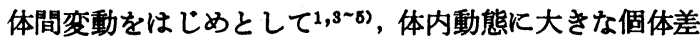
が存在することが挙げられ(1)，また，その血墏中漊度に は大きな日内㚆動があることも知られている8)。

VPA の血墏中濃度の測定においては早朝服用前の採 血が最す適しているといわれているが7,8)，Schobben ら はこの時期でさえも同一患者における血墏中濃度の日間 変動は20\%以上になると報告している2).

我々は健常成人に VPA を5 日間反復投与し，6 日目 の $9 \mathrm{a} . \mathrm{m}$. の投与直前と投与後における経時的な採血に 
より，VPA の投与量と血清中総濃度および非結合形濃 度との関係について検討した．また服用後の血清中総濃 度および血清中非結合率の, 服用前の值に対する变化率 と, 総濃度の上昇に対する非結合率の上昇の程度につい ても，あわせて検討したので報告する.

\section{対角および方法}

\section{1. 対}

7 名の健常成人（男 5 名，女 2 名，年令 $24 \sim 28$ 才) に VPA 錠 (Depakene ${ }^{\circledR} 200 \mathrm{mg}$ 錠, 協和発醉) $400 \mathrm{mg}$ (200 $\mathrm{mg} \times 2$ 錠）を， 9 a.m.と 9.p、m:の1 日 2 回，5 日間と

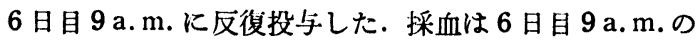
投与前と，投与後 $10,20,30,45,60,90,180,360$ 分 の合計 9 点で行った．サンプル採取後はただちに 2500 $\mathrm{rpm}, 5$ 分間にて遠心分離し, 得られた血清63検体を測定 試料とした. 血清は測定まで $-20^{\circ} \mathrm{C}$ にて凍結保存した。

\section{2. 测定方法}

測定は螢光偏光免疫測定法による Abbott-TDX を用 いて行った．また，血清中非結合形薬物濃度測定には遠 心型蛋白結合試験器 MPS-3 (アミコン社製) を用い, 血清から限外ろ過液を分離し測定試料とした。

\section{3. 测定值の解析}

測定値の解析は非線形最小二乗法に基づくプログラム MULTI を用い，計算は修正 Marquardt 法を用いて行 った.

\section{耛果 \\ 1.VPA 投与旦と血消中䋓灌度との関係}

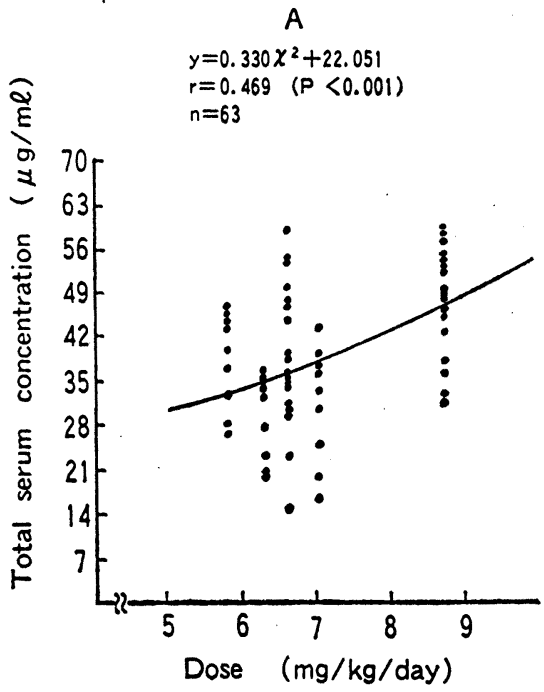

VPA の投与量と血清中総濃度との間には非線形性が 認められた (Fig. 1 A). VPA の投与量は7.1土1.1 $\mathrm{mg} / \mathrm{kg} /$ day (mean $\pm \mathrm{S} . \mathrm{D} . \mathrm{n}=7$ ) であり，その範囲は $5.8 \sim 8.7 \mathrm{mg} / \mathrm{kg} / \mathrm{day}$ であった (Table 1$)$. 総濃度は $15.0 \sim 59.7 \mu \mathrm{g} / \mathrm{ml}$ の範囲であり, mean \pm S.D.は39.1士 $11.2 \mu \mathrm{g} / \mathrm{ml}(\mathrm{n}=63)$ を示した. 回帰式は $\mathrm{y}=0.330 \mathrm{x}^{2}+$ $22.051(\mathrm{r}=0.469, \mathrm{p}<0.001)$ の 2 次曲線を示し有意な 相関が認められた。

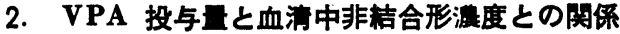

VPA 投与量と血清中非結合形濃度との間飞もまた， 非線形性が認められた (Fig. $1 \mathrm{~B})$. 非結合形濃度は $0.9 \sim 5.9 \mu \mathrm{g} / \mathrm{ml}$ の範囲であり, mean土S.D.は3.0土1.3 $\mu \mathrm{g} / \mathrm{ml}(\mathrm{n}=63)$ を示した. 回㷌式は $\mathrm{y}=0.037 \mathrm{x}^{2}+1.151$ $(\mathrm{r}=0.456, \mathrm{p}<0.001)$ の 2 次曲線を示し有意な相関が 認められた。

\section{3. 最終投与後の血消中総湿度の変化率}

6 日目の $9 \mathrm{a} . \mathrm{m}$. 飞抹ける投与前の血清中総濃度飞対 する，投与後 360 分までの総濃度变化率の経時的変化を 示した (Fig. 2). 最も高い変化率を示したのは投与後 60分で, $84.0 \pm 29.9 \%(\operatorname{mean} \pm$ S.D. $\mathrm{n}=7$ ) であり, そ の範囲は 55.4 134.8\% と 2 倍以上の個体差を示した. 投与後 360 分に拈いても变化率は $37.4 \pm 11.5 \%$ (mean土 S.D. $\mathrm{n}=7$ ) で，その範囲は22.5 54.9\%と 2 倍以上の

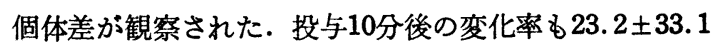
\% (mean \pm S.D. $\mathrm{n}=7$ ) で， その範囲は 1.8 101.4\% を示し，VPA は absorption lag time がほとんど見ら れないことが示唆された (Table 1). 各採血時点に打け る变化率の变動係数 (C.V.) は投与後 10 分で最大值

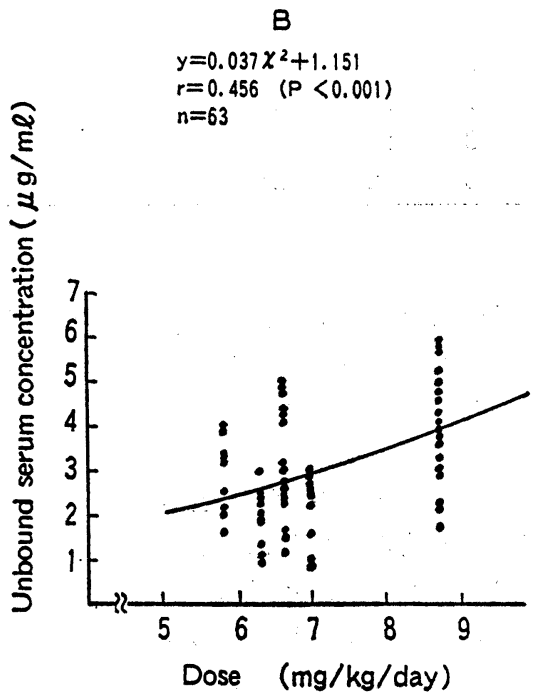

Fig. 1. Total (A) and Unbound (B) Serum Concentrations on VPA Dose 


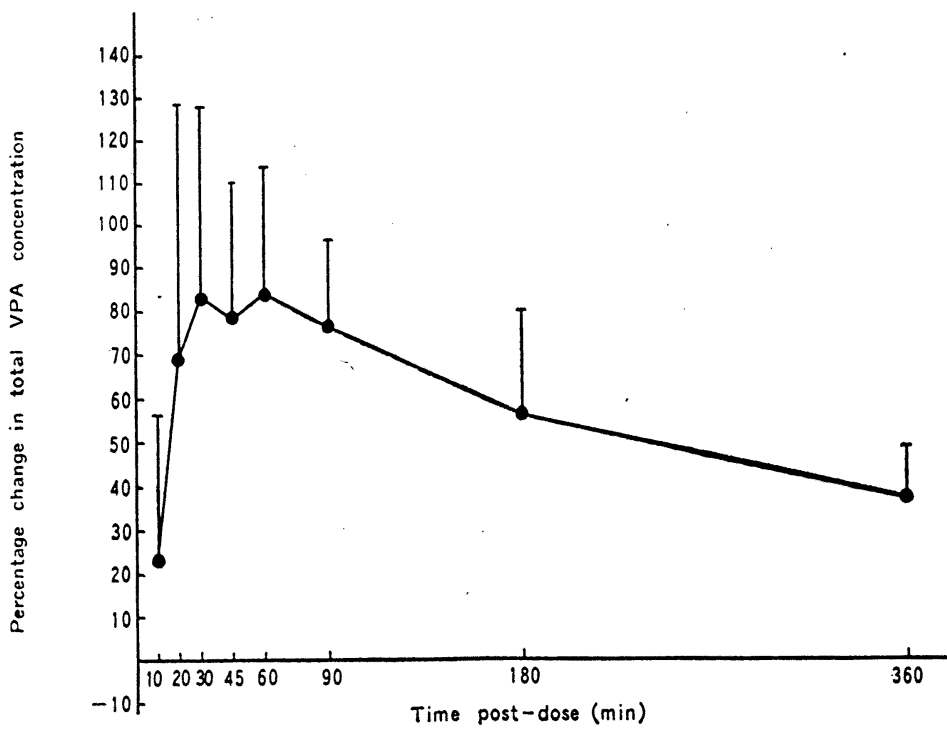

Fig. 2. The Mean Percentage Change in Post-dose Total VPA Concentration ( \pm S.D.) Following a Single Administration of the Usual Dose of VPA

Teble 1. The Minutely Percentage Change in Total Serum Concentration Following the Administration of the Usual VPA Dose is Listed for Each Subject

The sex, weight, age, daily dose and the pre-dose total serum concentration is also shown.

\begin{tabular}{|c|c|c|c|c|c|c|c|c|c|c|c|c|c|c|}
\hline \multirow{2}{*}{$\begin{array}{l}\text { Subject } \\
\text { number }\end{array}$} & \multirow{2}{*}{ Sex } & \multirow{2}{*}{$\begin{array}{c}\text { Weight } \\
(\mathrm{kg})\end{array}$} & \multirow{2}{*}{$\begin{array}{c}\text { Age } \\
\text { (years) }\end{array}$} & \multirow{2}{*}{$\begin{array}{c}\text { Daily } \\
\text { dose } \\
(\mathrm{mg} / \mathrm{kg}) \\
\end{array}$} & \multirow{2}{*}{$\begin{array}{l}\text { Pre-dose total serum } \\
\text { concentration } \\
(\mu \mathrm{g} / \mathrm{ml})\end{array}$} & \multicolumn{9}{|c|}{ Change in total serum VPA concentration(\%) } \\
\hline & & & & & & Pre-dose & $10 \mathrm{~m}$ & $20 \mathrm{~m}$ & $30 \mathrm{~m}$ & $45 \mathrm{~m}$ & $60 \mathrm{~m}$ & $90 \mathrm{~m}$ & $180 \mathrm{~m}$ & $360 \mathrm{~m}$ \\
\hline 1 & M & 61 & 25 & 6.6 & 34.4 & 0 & 1.8 & 39.3 & 45.3 & 58.8 & 57.8 & 72.4 & 37.0 & 29.1 \\
\hline 2 & $\mathrm{~F}$ & 46 & 24 & 8.7 & 32.2 & 0 & 3.4 & 13.3 & 33.2 & 52.5 & 69.4 & 65.6 & 45.5 & 39.7 \\
\hline 3 & M & 61 & 28 & 6.6 & 15.0 & 0 & 101.4 & 161.9 & 162.3 & 134.7 & 134.8 & 109.9 & 98.3 & 54.9 \\
\hline 4 & $\mathbf{M}$ & 64 & 28 & 6.3 & 20.0 & 0 & 3.7 & 16.3 & 83.1 & 62.3 & 80.5 & 71.9 & 61.6 & 39.0 \\
\hline 5 & M & 69 & 26 & 5.8 & 26.8 & 0 & 5.8 & 48.7 & 68.8 & 75.0 & 66.0 & 61.7 & 38.8 & 22.5 \\
\hline 6 & $\mathrm{~F}$ & 46 & 25 & 8.7 & 38.4 & 0 & 27.3 & 42.0 & 53.5 & 44.9 & 55.4 & 49.9 & 30.1 & 25.6 \\
\hline 7 & M & 57 & 28 & 7.0 & 16.7 & 0 & 19.1 & 160.0 & 136.2 & 118.0 & 124.2 & 101.9 & 83.0 & 50.9 \\
\hline Mean & & 58 & 26 & 7.1 & 26.2 & 0 & 23.2 & 68.8 & 83.2 & 78.0 & 84.0 & 76.2 & 56.3 & 37.4 \\
\hline S.D. & & 8 & 2 & 1.1 & 8.5 & 0 & 33.1 & 59.5 & 44.9 & 32.0 & 29.9 & 20.2 & 23.9 & 11.5 \\
\hline
\end{tabular}

$(142.7 \%) ， 90$ 分で最小值 $(26.5 \%)$ を示した. 投与前 の総濃度值が低い被験者 3 および 7 は, 投与後の変化率 が極めて大きな值を示し, 投与後 360 分においても同様 の傾向を示した.

\section{4. 最終投与後の血消中非結合率の变化率}

投与前の血清中非結合率に対する, 投与後 360 分まで の非結合率変化率の経時的変化を示した (Fig. 3). 最 も高い変化率を示したのは投与後 90 分で，26.6土33.2\% （mean \pm S.D. $\mathrm{n}=7$ ） であり，その範井は-4.9〜94.6 \%と20倍もの個体差を示した. 投与後 360 分においてむ
変化率は9.4土18.0\% (mean \pm S.D. $\mathrm{n}=7)$ で，その範 囲は - 18.3 34.5\% と 3 倍の個体差を示した（Table 2). 各採血時点に拉ける变化率の C.V. は投与後 10 分 で最大値 $(430.6 \%) ， 45$ 分で最小值 $(100.4 \%)$ を示し た. また，総濃度の变化に伴って非結合率も変化してお り，VPA と血清蛋白との結合に拈ける平衡は，迅速に 達成されるものと思われる.

一方, 血清中総濃度の変化率は 7 名ともすべての採血 時点で正の值を示したが, 非結合率の変化率では, 血清 中総蛋白，血清中アルブミン，血清中総ビリルビン，血 


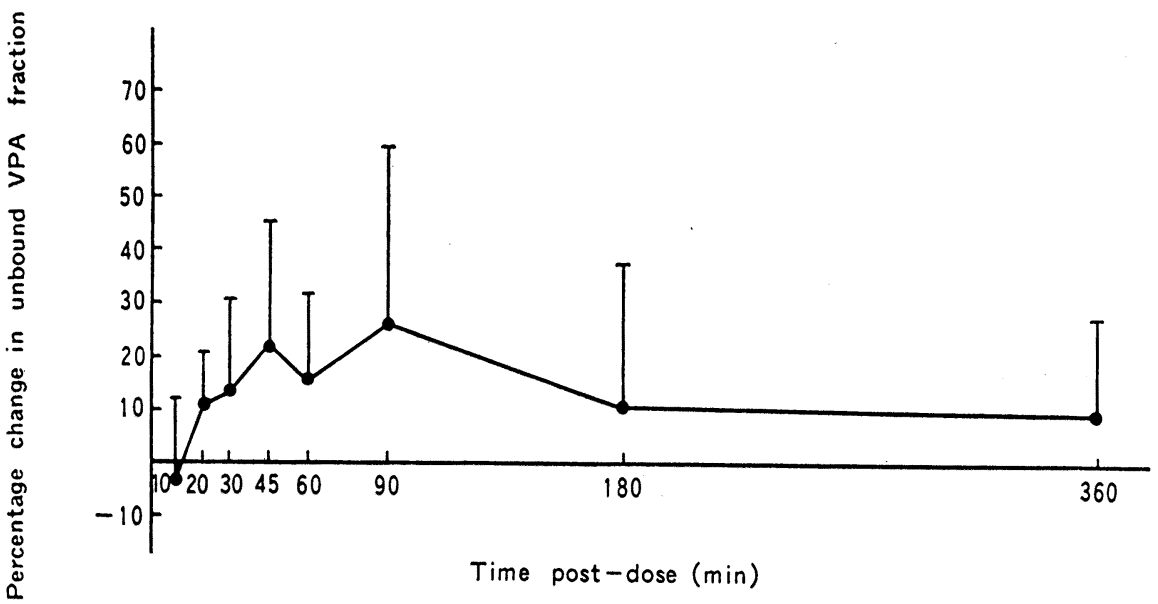

Fig. 3. The Mean Percentage Change in Post-dose Unbound VPA Fraction ( \pm S.D.) Following a Single Administration of the Usual Dose of VPA

Table 2. The Minutely Percentage Change in Unbound Serum Fraction Following the Administration of the Usual VPA Dose is Listed for Each Subject

\begin{tabular}{ccrrrrrrrr}
\hline \multirow{2}{*}{$\begin{array}{c}\text { Subject } \\
\text { number }\end{array}$} & \multicolumn{7}{c}{ Change in unbound serum VPA fraction (\%) } \\
\cline { 2 - 10 } & Pre-dose & \multicolumn{1}{c}{$10 \mathrm{~m}$} & \multicolumn{1}{c}{$20 \mathrm{~m}$} & $30 \mathrm{~m}$ & \multicolumn{1}{c}{$45 \mathrm{~m}$} & $60 \mathrm{~m}$ & $90 \mathrm{~m}$ & $180 \mathrm{~m}$ & $360 \mathrm{~m}$ \\
\hline 1 & 0 & 2.6 & 13.2 & 28.9 & 17.1 & 17.1 & -3.9 & 22.4 & -5.3 \\
2 & 0 & 19.6 & 7.1 & 23.2 & 33.9 & 35.7 & 94.6 & 44.6 & 32.1 \\
3 & 0 & -7.3 & -6.1 & -22.0 & -13.4 & -14.6 & -4.9 & -32.9 & -18.3 \\
4 & 0 & -16.4 & 5.5 & 14.5 & 67.3 & 18.2 & 32.7 & 10.9 & 34.5 \\
5 & 0 & -23.4 & 3.9 & 14.3 & 10.4 & -1.3 & -3.9 & -24.7 & 0 \\
6 & 0 & 15.6 & 26.0 & 1.3 & 16.9 & 24.7 & 32.5 & 26.0 & 6.5 \\
7 & 0 & -16.1 & 23.2 & 32.1 & 26.8 & 28.6 & 39.3 & 30.4 & 16.1 \\
Mean & 0 & -3.6 & 10.4 & 13.2 & 22.7 & 15.5 & 26.6 & 11.0 & 9.4 \\
S.D. & 0 & 15.5 & 10.5 & 17.3 & 22.8 & 16.3 & 33.2 & 26.9 & 18.0 \\
\hline
\end{tabular}

清中遊離脂肪酸のいずれの濃度も正常範囲にあるにるか かわらず, 被験者 3 がすべての採血点で負の値を示し， 総濃度が上昇しても非結合率は必ずしも上昇しないこと を示している.

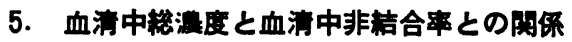

これまでに VPAの血清中非結合率は, 総濃度が上昇 するにつれて徐々に增加する傾向を示すとの報告がある

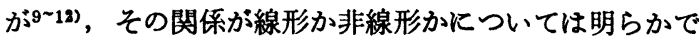
なく, 総濃度から非結合形濃度を予測する場合の問題点 として挙げられる。我々の結果は非線形性が認められた (Fig. 4). 今回得られた総濃度範囲 $(15.0 \sim 59.7 \mu \mathrm{g} / \mathrm{ml})$ に护ける非結合率は7.5 $\pm 1.3 \%($ mean \pm S.D. $\mathrm{n}=63)$
であり，その範囲は 4.6〜10.9\% であった。回帰式は $\mathrm{y}=1.063 \times 10^{-3} \mathrm{x}^{2}+5.732(\mathrm{r}=0.701, \mathrm{p}<0.001)$ の 2 次 曲線を示し，有意な相関が認められた。

\section{考寮}

個体間において VPA の投与量と血漿中濃度との間に 弱い相関が存在することが，多くの研究で報告されてい $3^{9,13 \sim 16)}$. しかし, この関係が線形か非線形かについて は，まだ結論がでていない，今回の我々の結果では，総 浱度・非結合形濃度のいずれにおいても2 次曲線で示さ れる非線形性が認められた. VPA 投与量と血墏中総濃 度との関係について, Vadja らは線形・非線形いずれの 


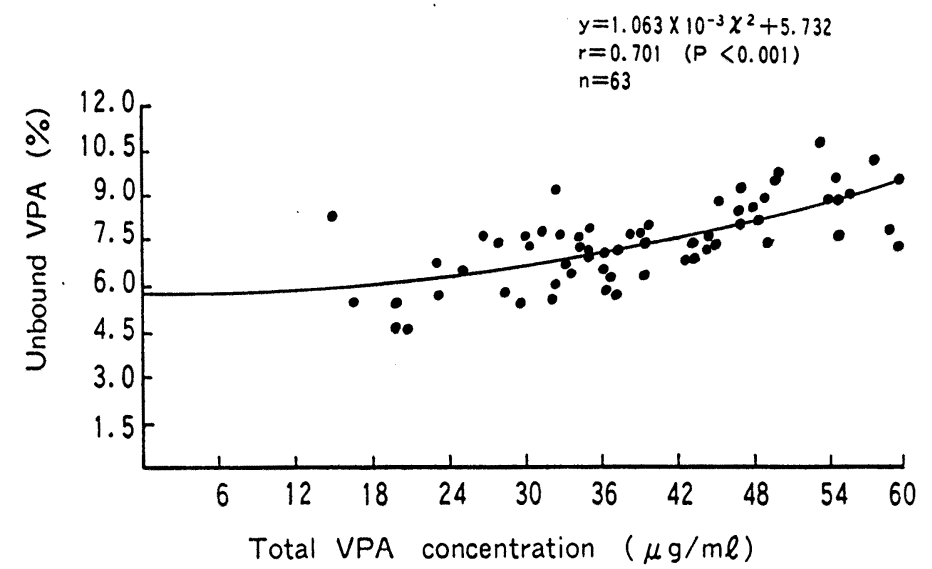

Fig. 4. Relationship between Total VPA Concentration and $\%$ Unbound VPA

関係も報告している4,17). しかしながら非線形を示すと いら報告では, 曲線が凸状を示し4), 我々の結果とは異な っている.一方，Klotz らは良好な線形性を報告してい るが(18), Minns ら, Bruni らは線形性は弱いことを(15,16), May らは線形性はみられなかったことを報告してい $ろ^{19)}$.これらの異なる結果の理由としては, 対象となっ た被験者, 採血時刻, 採取試料数がその要因となり,こ れらに加えて検討した血中濃度範囲にも差が認められて いることが考えられる。また Gram らはVPA の高用 量投与では, 血清中濃度の上昇率は緩徐となり, 投与㫣一 血清中濃度曲線は凸状を示すと報告しており ${ }^{20)}$, 今回得 られた 2 次曲線が低用量投与による結果であることを考 えると，VPA は投与量により体内動態が変化すること が示唆される.

最終投与後, 各採血時点における総濃度变化率の C. V. は，吸収相においてより大となり，堀らの報告にあ るように21)，VPA の吸収速度の個体差がその主たる原 因と思われる．また，総濃度の変化に伴い速やかに非結 合率も変化し, 結合の平衡は迅速に成立することが示唆 された．投与後 360 分においても，総濃度と非結合率の 変化率はいずれるかなりの個体間変動を示したが（総濃 度 : C.V. 30.7\%, 非結合率 : C.V. 191.5\%), 総濃度 の变動は時間経過とともに低下する傾向を示した.

VPA の血清中非結合率は総濃度の上昇に伴い非線形 的に上昇する傾向を示し, 総濃度から非結合率を推定す ることを難しくしている，また，総濃度の上昇に伴い非 結合率が低下する例がみられたことは興味深い。

我々の研究において, 総濃度と非結合率のいずれの変 化率にる大きな個体間変動がみられた理由としては，第 一に吸収率の差異が考えられる，VPA は経口投与後は 迅速にしかも完全に吸収されるとみなされているが22)，
十分に検討された報告は現在までのところはみられな (20). 第二に吸収相に打ける総濃度変化率の個体間变動 は消失相に比べ大きな値を示し, 吸収速度の差異もその 原因と考えられる。一方，VPA ではカルバマゼピンで 報告されているような ${ }^{23)}$ autoinduction は報告されてい ない24). 最後に可能性の最も高い理由としては, 総濃度 の変化に伴う非結合率の変化によるものが考えられる. VPA の体内からの消失は unbound fraction 依存性を 示し ${ }^{25,26)}$ ，このため非結合率の変化に伴って VPA の分 布および代謝が経時的に变化し，消失速度に大きな個体 差が生ずるのではないかと推測される．なおこれに関連 して, VPA のクリアランスに diurnal variation がみ

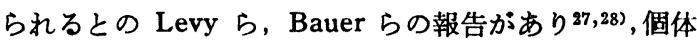
間変動の理由については，これを含めて検討する必要が あると思われる。

\section{引用文献}

1) P.Loiseau, A. Brachet, P. Henry, Epilepsia, 16, 609 (1975).

2) F.Schobben, E. van der Kleijn, T.B.Vree, Ther.Drug Monitoring, 2, 61 (1980).

3) P.Loiseau, B.Cenraud, R.H.Levy, R. Akbaraly, A. Brachet-Liermain, M.Guyot, P.L. Morselli, Clin. Pharmacokinetics, 7, 544 (1982).

4) F.J.E.Vadja, O.H.Drummer, P.M.Morris, J. J. Mcneil, P. F. Bladin, Clin. Exp. Pharmacol. Physiol., 5, 67 (1978).

5) K. Wulff, H. Flachs, A. Würtz-J $\phi$ rgensen, L. Gram, Epilepsia, 18, 149 (1977).

6) J. J. Marty, C. J.Kilpatrick, R.F.W. Moulds, Br.J.Clin. Pharmacol., 14, 399 (1982).

7) R. Gugler, G. E. von Unruh, Clin. Pharmacokinetics, 5, 67 (1980). 
8) D. W. Chadwick, Clin. Pharmacokinetics, 10, 155 (1985).

9) B.J. Wilder, B. J. Karas, "Antiepileptic Drugs", 2nd ed. by D. M. Woodbury, J.K. Penry, C.E. Pippenger, Raven Press, New York, 1982, pp. 591-599.

10) R. H. Levy, A. A. Lai, "Antiepileptic Drugs", 2nd ed. by D. M. Woodbury, J.K. Penry, C. E. Pippenger, Raven Press, New York, 1982, pp. 555-565.

11) R.Gugler, G. Mueller, Br.J.Clin. Pharmacol., 5, 441 (1978).

12) I. H. Patel, R.H. Levy, Epilepsia, 20, 85 (1979).

13) E. Mesdjian, C. Dravet, J. Roger, "Metabolism of Antiepileptic Drugs", ed. by R.H. Levy, W.H. Pitlick, M. Eichelbaum, J. Meijer, Raven Press, New York, 1984, pp.115-125.

14) D. M. Turnbull, M.D. Rawlins, D. Weightman, D. W. Chadwick, Ann. Neurol., 14, 38 (1983).

15) R. A. Minns, J.K. Brown, D. H. R. Blackwood, J. K. Mcqueen, Lancet, 1, 677 (1982).

16) J. Bruni, B.J. Wilder, L.J. Willmore, R. J. Perchalski, H.J. Villarreal, Clin. Pharmacol. Ther., 24, 324 (1978).

17) F.Vadja, P.Morris, O. Drummer, P. Bladin, "Clinical and Pharmacological Aspects of Sodium Valproate (Epilin) in the Treatment of Epilepsy", ed. by N. J. Legg, MCS Consultants, Turnbridge Wells, 1976, pp.92-100.

18) U.Klotz, Arzneim.-Forsch./Drug Res., 27, 1085 (1977).

19) T. May, B. Rambeck, Ther. Drug Monitoring, 7, 387 (1985).

20) L. Gram, H. Flachs, A. Würtz-J $\phi$ rgensen, J. Parnas, B. Andersen, Epilepsia, 20, 303(1979).

21）堀了平, 奥村勝彦, 斎藤一文字, 安原真人, 越 川富雄, 橋田 亨, 奥野武彦, 中川照真, 山岡 清, 㯺床薬理, 15, 535 (1984).

22) U. Klotz, K. H. Antonin, Clin. Pharmacol. Ther., 21, 736 (1977).

23) M. Eichelbaum, K. Ekbom, L. Bertilsson, V. A. Ringberger, A. Rane, Eur. J. Clin. Pharmacol., 8, 337 (1975).

24) R. Gugler, A. Schell, M. Eichelbaum, W. Fröscher, H.-U.-Schulz, Eur. J. Clin. Pharmacol., 12, 125 (1977).

25) R. H. Levy, K. M. Koch, Drugs, 24, 543 (1982).

26) R.H. Levy, Ther. Drug Monitoring, 2, 199 (1980).

27) R. H. Levy, J. S. Lockard, I.H. Patel, W.C. Congdon, J. Pharm. Sci., 66, 1154 (1977).

28) L. A. Bauer, R. Davis, A.Wilensky, V. Raisys, R.H.Levy, Clin. Pharmacol. Ther., 37, 697 (1985). 